\title{
Phraseological Anglicisms in German: A look at a satirical TV program
}

\author{
Sabine Fiedler ${ }^{1}$ \\ University of Leipzig
}

\begin{abstract}
Due to its role as a lingua franca, English has become a major source of language influence worldwide. This article addresses the impact of English on German. Contact-induced influences can be observed at all levels of the linguistic system in German, extending from preferences for particular morphemes to the structure of texts and genres. This study focuses on the largely under-studied area of phraseology. Phraseological Anglicisms, i.e. word-groups and sentence-like units such as catchphrases, proverbs, formulae and slogans of English origin, are gaining ground, particularly in fields like media, journalism, advertising and entertainment. The phenomenon is analyzed here via the example of the German satirical TV program heute-show. It is shown that the modification of phraseological units is an oft-used technique of political satire. Phraseological Anglicisms represent about one third of all occurrences in the examined data set, and thus play an important role. They most commonly take the form of political slogans, titles of films and brand names. The discussion focuses on particular types of modification and whether the German audience understands and appreciates them.
\end{abstract}

Keywords: Anglicism, phraseology, tv satire, humour, modification, German

\section{Introduction}

Due to its ubiquity, above all in the media, English is exercising an enormous

1 Corresponding author: Institut für Anglistik, Beethovenstraße 15 D-04107, Leipzig, Germany.

Email: sfiedler@uni-leipzig.de 
influence on other languages. This has been documented in a large number of publications (for an overview see Görlach, 2002; Pulcini, Furiassi \& Rodríguez González, 2012). This article will explore this phenomenon from a German perspective. Studies in this field have so far focused on simple and complex words. Larger items, so-called phraseological units (henceforth PUs) have not attracted much interest. This article will contribute to closing this gap. It deals with the impact that English has regarding word-groups and sentence-like units, such as catchphrases, proverbs, formulae and slogans. A special focus will be put on their modification, i.e. on the techniques of employing PUs in innovative ways to convey meaning in a specific stylistic manner. The article will shed light on this theme using the example of a German satirical TV program. Before this specific topic is addressed, a survey of English influence on the German language will illustrate the scope and variety of impact that English has on German at different levels of the linguistic system.

\section{The impact of English on the German language: an overview}

A considerable amount of literature has been published on the impact of English on the German language. Among the most important investigations are large-scale descriptive studies by Carstensen \& Galinsky (1963), Carstensen (1965), Fink (1970), Viereck (1980), Yang (1990), Lehnert (1990), Schelper (1995), Glahn (2002), Onysko (2007), and Burmasova (2010).

The influence of English can be detected across all levels of the linguistic system. Those in the fields of phonetics/phonology and orthography are of minor importance. Occasionally, non-English words are pronounced in an English manner (e.g. the Belgian place name Waterloo). Incorrect spellings (e.g. Addresse for Germ. Adresse) can be attributed to the frequency of lexical items in English especially in computer-mediated communication. The use of the apostrophe $+s$ for the genitive case as in the English model can mainly be observed in semi-official documents and on notice boards (e.g. Kerstin's Kaffestube, En. 'Kerstin's café'). Lawrence Norfork's novel Lampiere's Dictionary (1992) was rendered as Lampiere's Wörterbuch (1993).

As regards morphology, the suffix -ing is gaining ground, particularly in youth culture (e.g. Faulenzing, En. 'lazing about', Gassigehing, En. 'walking the dog'), following its use in English loanwords such as Rafting and Skating. Barz (2008, p. 51) expects a further group-specific dissemination of this suffix and, in the long run, its use in other registers of the German language. Another contact-induced change in German word formation is the growing use of open compounds, both in the names of official institutions (e.g. Paul Flechsig Institut, Peter Lang Verlag) and every-day words (e.g. 
Mandel Splitter, En. 'almond slivers', Geflügel Salat, En. 'chicken salad'). To evaluate this development one must recognise that, in contrast to English, where compounds are inconsistently used in open, solid or hyphenated forms (cf. Quirk et. al., 1985, p. 1569), German compounds are spelt as one word (e.g. Jugendkultur, En. 'youth culture'), with the two constituents occasionally joined by the linking morpheme $s$ (e.g., Staatsbesuch, En. 'state visit' from Staat and Besuch). Geflügel Salat, En. 'chicken salad', instead of Geflügelsalat is therefore considered awkward and unnatural by most German speakers.

A third morphological innovation, the growing popularity of phrasal compounds, i.e. compounds headed by a noun with a phrasal non-head (Lieber 1992; cf. also Bauer, Lieber \& Plag, 2013, p. 56), also deserves mention. Examples include Tit-for-Tat Verhandlung (En. 'tit-for-tat negotiation'), Big-Stick-Politik (En. 'big-stick policy'; cf. the catchphrase Speak softly and carry a big stick, popularized by Th. Roosevelt) and „Einmal-im-Leben"-Ereignis (En. 'once-in-a-lifetime event'). The English origin of the phrasal elements and the existence of a traditional German alternative in the latter case (ein einmaliges Ereignis) are indicative of English influence (cf. Lawrenz, 2006).

Syntactic influences include the use of the preposition in preceding years (e.g. In 2005 habe ich ... as opposed to 2005 habe ich .../Im Jahr 2005 habe ich ...) and the use of Adj + Adj to express continual change (e.g. Es wurde dunkler und dunkler, En. 'it was getting darker and darker', instead of Es wurde immer dunkler). In addition, Schelper (1995, p. 15) cites the use of possessive pronouns to designate parts of the body (e.g. Er stützte seinen Kopf in seinen Arm, En. 'He held his head in his hand/arm' as opposed to ... den Kopf in den Arm, En. 'the head in the hand/arm') and the analytic comparison of adjectives by means of mehr (e.g. das mehr normale Verhalten, En. 'the more usual behaviour' instead of das normalere Verhalten) as potential examples of structural influence, which she classifies as "Lehnsyntax" (loan syntax).

The impact of English can be felt especially at the lexical level. Direct borrowings include loanwords, false loans and hybrid loans (cf. Pulcini, Furiassi \& Rodríguez González, 2012, p. 6). Loanwords occur in their original English form in German, i.e. they are non-adapted and can therefore easily be detected as foreign (e.g. Homepage, Freestyle). ${ }^{2}$ False loans (also called pseudo-Anglicisms, cf. Onysko 2007, p. 52) are made up of English material, but either do not exist in English or have a different meaning in English (e.g., Handy means 'mobile phone' when used in

2 Because of differences between the sound systems of English and German, however, phonological integration usually takes place (cf. job [dzpb] $\rightarrow$ Job [dzop / top]; worst case [w3:st keIs] $\rightarrow$ [vc:st ke:s]). 
German, but means 'useful' in English; Oldtimer means 'classic car', when used in German, while old timer or old-timer is slang for an old person in English). ${ }^{3}$ Words with slightly differing constituents in the recipient language (e.g. Happy End for happy ending; Gin-Tonic for gin and tonic) can be regarded as a subgroup among these. Hybrid loans, "loan blends" in Haugen's (1950) terminology, combine English and German material (e.g. fairerweise, En. 'in a fair style'; Haarspray, En. 'hairspray').

Indirect borrowings are loan translations, also known as calques (e.g. Gipfelkonferenz after summit conference; Schrittmacher after pacemaker) and loan renditions, in which loose equivalents or the translation of only a part of the source unit can be found (e.g. Wolkenkratzer En. lit. 'cloud scraper' for skyscraper). These subtypes have been discovered in a large number of languages (cf. Pulcini, Furiassi \& Rodríguez González 2012).

In the case of semantic loans, a word that has already existed in the language changes its meaning according to the meaning of a similar word in the donor language. For example, the German verb realisieren, En. 'realise', traditionally means 'to put into practice/make happen', but due to English influence, has recently also come to be used in German to mean 'to become aware of'. ${ }^{4}$ A similar semantic expansion can presently be observed in the use of the German adjective/adverb ironisch/ironischerweiser: in addition to the basic meaning 'to say the opposite of what is intended (in a mocking way)', these words are now also used in the English fashion, meaning 'paradoxic(ally)' or 'unexpected(ly)'.

Influences are also felt at the level of text and genre. As regards the field of academic writing, a number of empirical studies have verified the existence of culture-specific thought patterns (Kaplan, 1966) and discourse styles, reflecting particular traditions in education and scientific work, as well as different ways of socialisation (Fiedler, 2014b). Due to the fact that the majority of German scientists today are obliged to publish in English, Anglo-American conventions of structuring academic articles (Introduction, Methods, Results, and Discussion, IMRAD for short) are increasingly found in German academic articles and beyond (Gordon, 2015, p. 301; Schneider, 2015, p. 217). As early as 1992, Hüllen (1992) pointed out:

Eine in solchen Texten festgestellte Universalität des wissenschaftlichen Stils

3 Cf. the comprehensive collection of these types of loans in Italian by Furiassi (2010) and Furiassi \& Gottlieb (2015).

4 Braselmann (2002, p. 311) describes the same development for French (realiser) and Spanish (realizar). 
[...] mag in der Tat mehr ein universal gewordener englischer als ein wirklich universaler Stil sein. ${ }^{5}$

With regard to genre, it should be mentioned that many TV formats of US origin have been adopted by German channels, formats which include talent shows, game shows and talk shows. English influence also includes gestures and symbols. A typical example of the latter is the use of the letter $Z$ to express sleep or boredom. It is increasingly supplanting the letter $R$, traditionally used in German in the same role (see pictures 1 and 2). In addition, emoticons, such as little x's and o's (representing kisses and hugs), can increasingly be found as closing signals in letters and text messages.

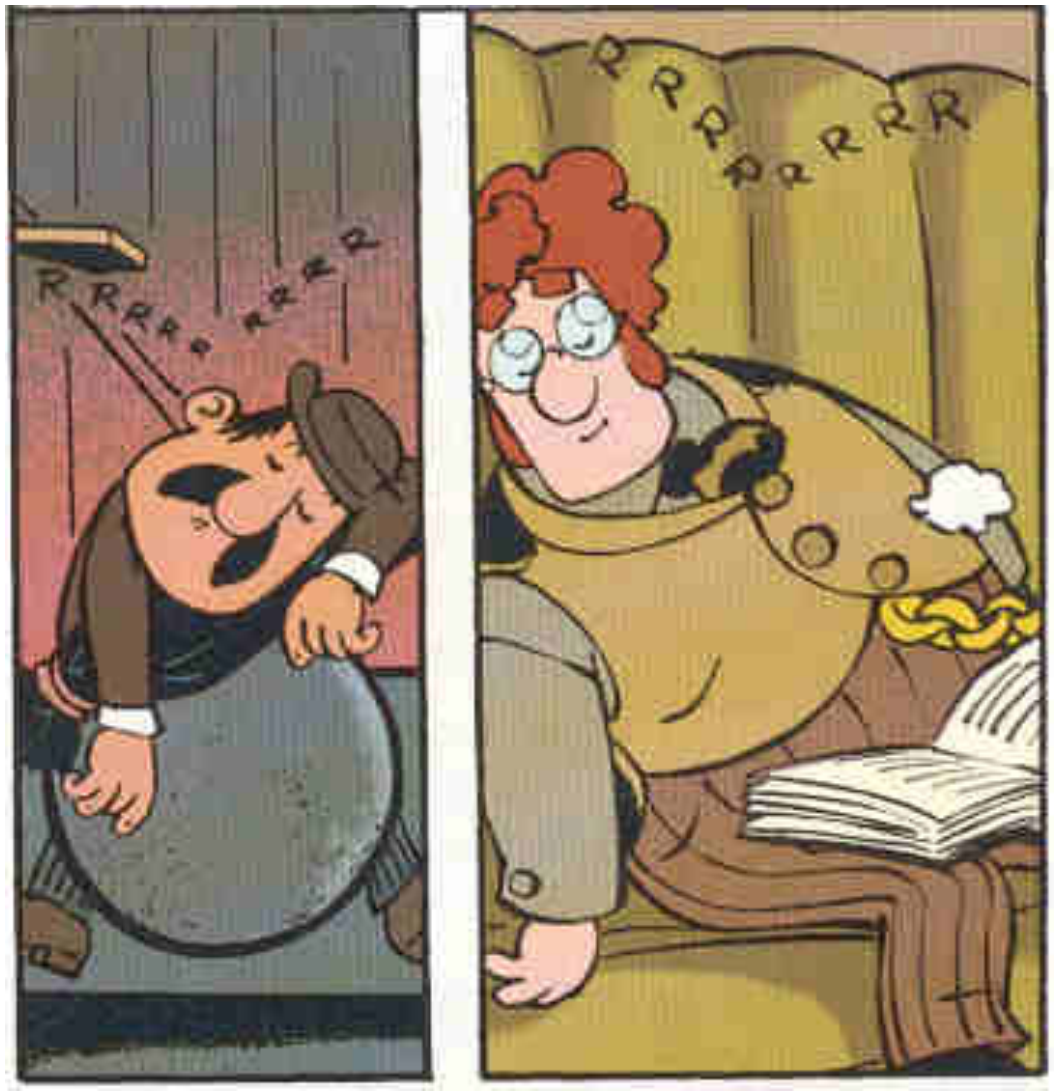

Picture 1. The use of R symbolizing sleep in a German comic magazine (MOSAIK 9/1999 p. 45)

5 The universal character of academic style that has been established [...] might in fact be more the case of an English style that has become universal than a really universal style. 


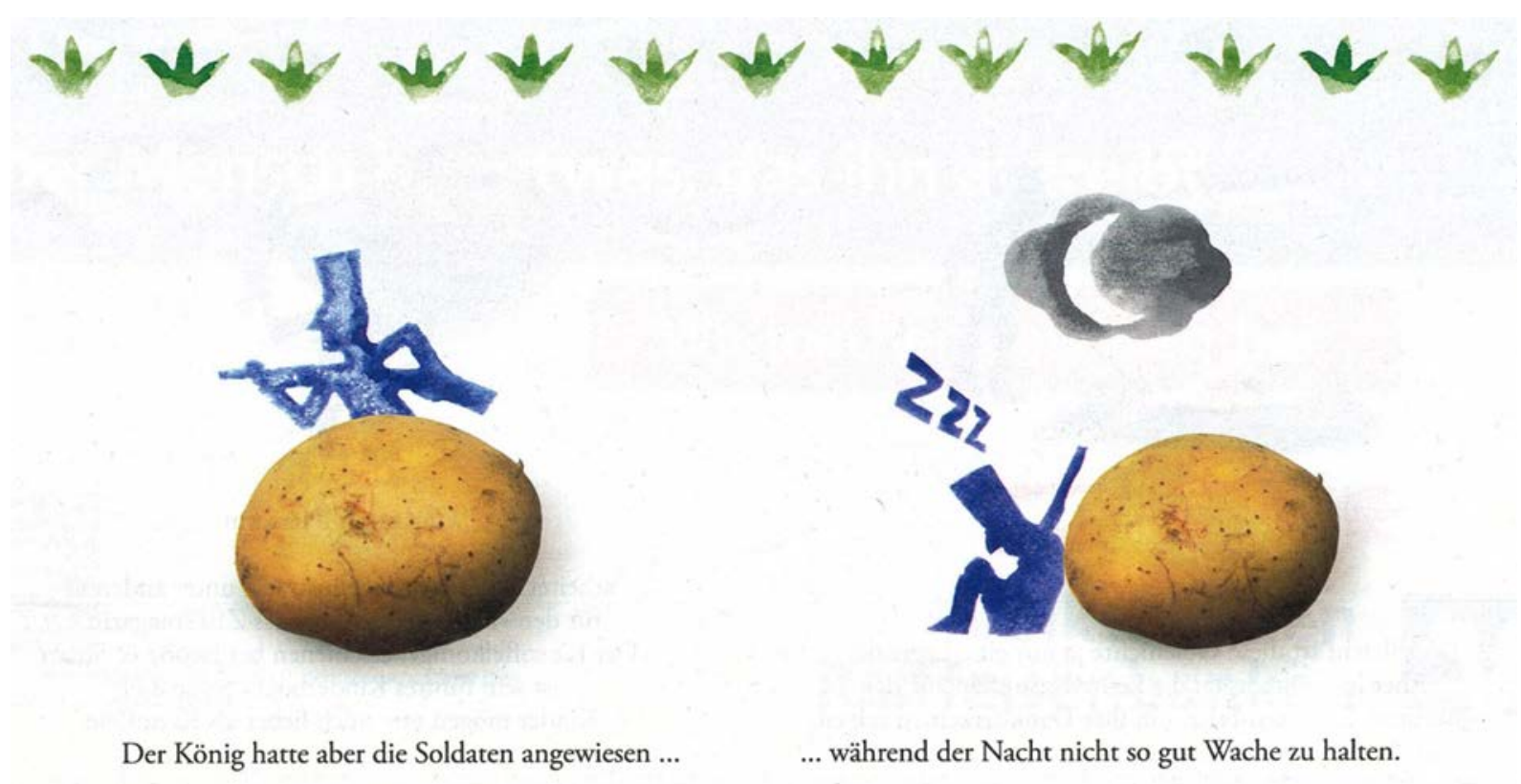

Picture 2. The use of Z symbolizing sleep in an illustrated story on the introduction of the potato to German agriculture in the 18th century published in a German newspaper (ZEIT Magazin 28 February 2013, from "Der Kartoffelkönig" by Christoph Niemann, Berlin: Jacoby \& Stuart 2013)

Thus, the influence of English extends from morphemes to entire genres. The remainder of this paper, however, will focus on the phrasicon (Granger, 2009), i.e. the inventory of communicative formulae, catchphrases, slogans and other multiword items. It will start with a definition and system of classification of phraseology and phraseological Anglicisms and then shed some light on their use in various communicative spheres with a focus on a news satire show.

\section{Phraseology}

\subsection{Definition and classifications}

There are five main defining characteristics of phraseological units (cf. Burger et al. 2007; Fiedler, 2007): (1) they have a polylexemic structure, i.e. PUs are word-groups or sentences; (2) they are characterised, in principle, by semantic and syntactic 
stability; ${ }^{6}$ (3) they are lexicalised, i.e. as ready-made units of the lexicon they are not created productively by the speaker/writer but reproduced; (4) they are mainly idiomatic; ${ }^{7}$ and (5) most of them have connotative features.

In the literature we find different ways to classify phraseological units. A basic division into word-groups (word-like PUs) and sentences (sentence-like units) seems to be of importance. When applying a structural-semantic classification, as is often done in phraseology, and applying it to the topic of this study, phraseological Anglicisms, we find the following types of units to be especially relevant (cf. Burger et al. 2007; Fiedler 2007):

- $\quad$ phraseological nominations (e.g. Fake News; etw. ist keine Raketenwissenschaft, cf. sth. is not rocket science)

- $\quad$ binomials (e.g. Meet and Greet; Brot und Butter, cf. bread and butter)

- $\quad$ proverbs (e.g. No risk, no fun; Solange die dicke Frau noch singt, ist die Oper nicht zu Ende, cf. it isn't over until the fat lady sings)

- $\quad$ restricted collocations (e.g. ein Problem adressieren, cf. to address a problem; ein Statement abgeben, cf. to make a statement)

- $\quad$ winged words/catchphrases (e.g. Big Brother (is watching you); Wem es in der Küche zu heiß ist, der sollte nicht Koch werden, cf. If you can't stand the heat, get out of the kitchen)

- $\quad$ routine formulae (e.g. So what?; Netter Versuch cf. Nice try).

A closer look at the examples given above reveals that the type of lexical material contained varies among them. Using the classifications of Haugen (1950) and Weinreich (1953) and their criteria of substitution and importation as a starting point, the phraseological borrowings may be divided into three main groups. The first group includes direct loans, i.e. phrases and sentences that have been imported in the English original (e.g. No risk, no fun). In contrast to these, there are indirect borrowings (or loan translations) whose lexical material has been fully substituted by morphemes of the recipient language, i.e. German (e.g. etw. ist keine

$6 \quad$ Within definite constraints, there are variants, however. The use of function words (prepositions, determiners etc.) can vary (e.g. in/by leaps and bounds) as well as lexical constituents (e.g. sweep sth. under the carpet/rug).

7 PUs can have different degrees of idiomaticity. At one end of the scale there are real idioms, i.e. fully opaque expressions. At the opposite end of the scale, we find fully transparent units, which are, however, legitimately included in the phrasicon because they are polylexemic, stable, and lexicalised. Idioms are therefore a subset of PUs.

$8 \quad$ The examples given in parentheses are part of the author's research. Their use (including frequency data is described in more detail in Fiedler, 2014a). 
Raketenwissenschaft - cf. sth. is not rocket science). A third group is constituted by hybrid constructions that are characterised, in Haugen's term, by partial substitution (e.g. einen guten Job machen - cf. to do a good job). Occasionally, a phraseological borrowing enters the German language in various forms, which are used interchangeably by individual speakers (e.g. aus dem Blauen heraus - out of the blue; fair enough - fair genug; Nice try - Netter Versuch).

\subsection{Playful modifications}

This study focuses on the modification of phraseological Anglicisms, i.e. on occurrences in which a PU is manipulated or transformed in a particular way according to the communicative needs of the language user (Fernando, 1996, p. 43). Modifications are found frequently in journalism and advertising, which increasingly feature Anglicisms (cf. Stefanowitsch, 2002; Piller, 2001; Fiedler, 2014a). For example, a group of companies called Leipziger (L), from my hometown, used the titles of English pop-songs in a recent advertising campaign (see pictures 3 and 4) replacing the word love with their logo, a stylized letter $L$. The modification (in this case a substitution) connects the pleasant connotations of the word love to the companies.

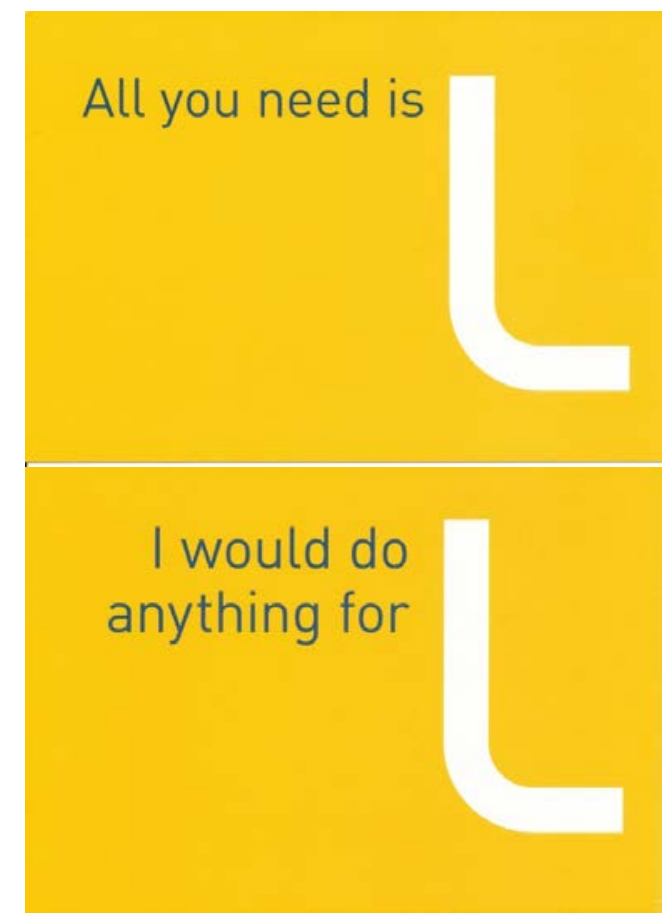

Pictures 3 and 4: Advertisements by Leipziger (www.L.de)

Modifications like these should not be mixed up with variants as described in 3.1 
and footnote 6 about stability. The English phrase the elephant in the room, for instance, entered the German language in several versions, as can be seen in the following examples:

Die Rasse sei der Elefant im Raum, über den keiner redet. So stand es vor der US-Präsidentschaftswahl im US-Magazin "Time". Nachdem Barack Obama gewonnen hat, wird der Elefant sichtbar und alle reden über ihn. Warum erst jetzt? (Die Welt 11 Nov 2008) (Race is the elephant in the room that nobody talks about. This was said before the US presidential election in Time Magazine. After B. Obama's victory the elephant becomes visible and everybody talks about it. Why only now?)

(2)

Und auch Al Gore fängt an, darüber zu reden. Umweltschützer wussten es natürlich schon immer, das ist wie der Elefant im Wohnzimmer. Das Problem ist, dass es den meisten Menschen nicht behagt, wenn ihre Ernährungsgewohnheiten kritisiert werden. (Frankfurter Allgemeine Zeitung 17Jan 2010) (And Al Gore as well starts talking about it. Environmentalists, of course, have always known it; it is the elephant in the living room. The problem is that most people don't like when their eating habits are criticized.)

(3) Die ganze Diskussion zeichnete sich dadurch aus, dass niemand das Offensichtliche erwähnte. Nach der englischen Redensart, dass der Elefant im Zimmer von allen Anwesenden ignoriert wird, sprach niemand von den muslimischen Schulen. (Neue Zürcher Zeitung 30 Oct 2006)（The whole discussion was characterized by the fact that nobody mentioned the obvious. Just as the English saying has it, that the elephant in the room is ignored by all present, nobody mentioned Muslim schools.)

In contrast to these variations (Elefant im Raum, Elefant im Wohnzimmer and Elefant im Zimmer for En. elephant in the room), modifications represent situational ad-hoc exploitations. They are a type of ludic linguistic behaviour (language play in Crystal's 1998 terminology). Playful modifications are a useful basis for our study, as marked uses like these provide insight into how entrenched these items have become in the German language. Advertisers and authors obviously presuppose the familiarity of consumers and TV viewers with the Anglicism. Otherwise their ads and jokes would not be successful.

\subsection{Phraseological Anglicisms in political satire: a pilot study}

Studies on comedy shows and political satire have shown that phraseological units 
often serve to create humour (cf. Fiedler, 2005, 2015; Norrick, 2007). Humour, as we know, is based on incongruity. We laugh at things that contradict our expectations and are out of place. With the characteristics described in section 3.1, PUs have rich potential to evoke humour. Proverbs, catchphrases, formulae and other items can be frequently found in innovative or 'marked' uses. For example, authors and hosts of comedy shows toy around with the two potential meanings that PUs have, creating phraseological puns, and modify them by exchanging elements or combining several items producing playful distortions to evoke specific stylistic effects and ultimately laughter. On the basis of these findings and given the fact that English words and phrases abound in entertainment and media due to the prestige of the language, i.e. its association with modernity and education, it might be useful to explore PUs that have their origin in English - phraseological Anglicisms.

\subsubsection{The heute-show}

The subject under investigation is the German satirical TV program heute-show. Airing Friday nights on the broadcast channel ZDF since 2009, it is one of the most popular German TV programs and attracts viewers of various age groups. ${ }^{9}$ The 30 minute show is an adaptation of the US news satire The Daily Show. It has a recurrent structure, with the comedian and journalist Oliver Welke presenting the weekly news along with funny and sarcastic commentary, fake experts and correspondents reporting from political events in the field, stereotypical characters such as a disgruntled senior foreign correspondent, an effusive admirer of Chancellor Angela Merkel and an East German with a Saxon accent and poor dress sense. The heuteshow is an expression of global developments in political humour. As regards its structure, it marks a shift from the German cabaret tradition towards AngloAmerican forms of political satire (cf. Jones, 2010). Its content, however, is straight from German media culture; the show focuses on German politics and on international politics seen from a German perspective. It includes well-known German comedians and integrates traditions of the channel ZDF, such as the animated cartoon characters Mainzelmännchen (cf. von Kleinen-Königslöw \& Keel 2013). The 20 programs from April 2016 to February 2017 analysed in this study address, in addition to various topics of German domestic politics, the UK's exit from the EU, the election of new Heads of State in Germany and Austria and the US Presidential Election.

Satire aims at more than just amusement; it also seeks to ridicule. This is true too for 
news and political satire shows, which are free from requirements of journalistic neutrality or fairness, and are per se unfair and subjective (Emde \& Scherer, 2016). According to Test (1991), aggression and judgement are among their main characteristics. Political satire can also be a challenge for the viewer. A high level of background knowledge is necessary to understand parody and ironic commentary on political issues in the way intended by the author. The heute-shows live audience therefore is an asset for the present analysis; audience reaction to a bit provides information on whether the premise of the bit was understood or not.

The heute-show is a mixture of humorous entertainment and political criticism. It manages to find a balance between the two approaches by a number of techniques. Among these is what Neil Postman (1986) called the "now this" format, in which an anchor jumps from one news item to the next. The show is a semantically complex genre combining the verbal code, i.e. the comedians' speech, with pictures, caricatures and other visual elements. Written elements such as printed captions supplement the host's oral monologue. The topics covered are also very diverse, from important political issues like the rise of right-wing extremism to trifles like a politician's appearance (e.g. Donald Trump's hairstyle); entertaining - and at times absurd - elements are blended with serious concerns. A wide variety of traditional types of verbal humour are employed including jokes, tongue twisters, dialects, puns, allusions and, not the least, phraseology.

English plays a role in the heute-show in various ways. Firstly, the use of the English language in Germany itself is repeatedly made the subject of satirical comments. For example, in the April 29th, 2016 episode, Welke mocks the Liberal Democrats' slogan German Mut ['German courage'], which was formed in analogy to German angst, a German loan in English, with a videoclip of a speech delivered at their party's convention in which Anglicisms are overused. In the November 25th, 2016 episode, in a report on a convention of Alternative für Deutschland $(A f D)$, a right-wing populist party, a heute-show correspondent proposes a billboard "AfD sucks - AfD saugt", explaining that the German translation was added especially for AfD voters, implying that they are poorly educated..$^{10}$ In a similar vein, it is popular in German comedy to mock politicians with poor English skills. The analysed programs, for example, include snippets of TV news programs of EU commissioner, Günther Oettinger, and of the German Federal Minister of Finance, Wolfgang Schäuble, struggling to speak English. Finally, the heute-show features captions that appear in print on screen from time to time in a graphics panel to the left of the host, and these often include

10 The scene evokes additional humour because the given literal German translation does not help in understanding the figurative meaning of the phrase. 
phraseological Anglicisms. These captions represent the focus of this pilot study.

The presentation of graphics and/or captions in juxtaposition with the anchor's spoken commentary (see the screenshots in pictures 5 through 8 ) is a satire strategy modelled on a US format exemplified by programs such as The Daily Show and The Colbert Report. ${ }^{11}$ The dialogic confrontation of these two types of speech (or voices), i.e. the anchor's oral monologue and the visually presented text, creates polyphony in the vein of Mickail Bakhtin (1963) (cf. Baym, 2005, p. 266). The funny or ironic comments are generally met with laughter and applause. In the majority of cases, Welke does not comment on them, but delays his speech or repeats words to give room for an audience reaction.

\subsubsection{Phraseological anglicisms in the heute-show}

Phraseological units are frequent elements in the captions. In the 20 programs that were analysed for this study, there were 165 captions with PUs in total, of which 50 were of English origin, i.e. phraseological Anglicisms. This means that each program included on average 2.5 phraseological Anglicisms in the captions. ${ }^{12}$

All the phraseological units in our data set are used in 'marked' or innovative ways (cf. Fiedler, 2007). For instance, humour is evoked by clashes in usage domains. An example, from the November 18th, 2016 episode, is a report on Barack Obama's last visit to Germany as the US President, accompanied by a poster in the style of a pop concert reading Obama Farewell Tour 2016. Another example, from the November 11th, 2016 episode, is the slogan Refugees Welcome, which viewers would presumably associate with the migrant crisis and reactions to it in Germany, over a Canadian flag, as commentary on the outcome of the US Presidential Election.

The most common type of modification is the substitution of phraseological elements by constituents that are closely related to the topic, as in the following

11 This style of graphics appearing on-screen next to a host began with news and/or commentary shows on cable news channels, and since Jon Stewart was satirizing these shows, he borrowed the practice. - I owe this interpretation to Shane Carlson.

12 The study focuses on direct borrowings (see section 3.1), i.e. items which are clearly recognizable as Anglicisms due to the English lexical material they include. For example, the catchphrases Das Trump Team, alluding to the TV series Das A-Team and Onkel Don's Hütte, alluding to Onkel Tom's Hütte in the December, 16 ${ }^{\text {th }}, 2016$ program were excluded from the data set despite their clear English origin (cf. The A-Team, Uncle Tom's Cabin), because they refer to the German translations of the titles. 
examples:

(4)

The Winner fakes it all (February 27th, 2017; cf. the pop-song The Winner Takes it all; the replacement of takes with fakes refers to Donald Trump's frequently false statements)

(5)

Fog off! (December 16th, 2016; during discussion of Brexit, a photograph shows Big Ben in fog)

(6)

Make America White Again (November 11th, 2016; cf. the slogan of Donald Trump's election campaign, Make America Great Again)

Hair Force One (September 30th, 2016; cf. Air Force One; allusion to D. Trump's hairstyle)

(8)

Brexit for One (December 16th, 2016; during a report on Theresa May, who was not invited to a EU summit dinner; cf. Dinner for one, a comedy sketch in English that has established itself a component of the New Year's Eve schedule of several German television stations)

It is also popular to include names of politicians in these creative manipulations, as in Forest Trump (September 30th, 2016), Schmidt happens (April 15th, 2016, in reference to Christian Schmidt), and Smells Like Martin Spirit (February 10th, 2017, in reference to Martin Schulz, a candidate for the German Chancellorship). By means of these intertextual references, authors intend to transfer the semantic contents of the substituted item to the new elements. In our first two examples, i.e. the association of Donald Trump with Forest Gump and the replacement of shit with the name of the German Minister of Food and Agriculture, the substitutions represent rather stark criticism. In the third example, the pop-song Smells Like Teen Spirit, is associated with the then newly nominated candidate for the position of German Chancellor, evoking youth.

Particular humorous effects can result when replacements are from the target language (i.e. German). The resulting phrases are reminiscent of Maccaronic poetry:

Einmischen impossible (April 15th, 2016; 'interfering impossible'; cf. the film title Mission Impossible)

I don't Kehr-Woche (September 16th, 2016; a mixture of I don't care and the typical Swabian tradition of Kehrwoche ['sweeping/cleaning week'], a week in which it is a resident's turn to clean the stairwell in the block of flats where they live; the expression was used to mark a politician's attitude in combination with his Swabian origin) 
Basis Instinct (October 28th, 2016; cf. the film title Basic Instinct; referring to a politician who had strayed from party lines [Germ. Basis 'basis'])

Maut Rushmore (December 9th, 2016; cf. Mount Rushmore; along with a picture showing the faces of two Bavarian politicians carved into granite as though their introducing motorway toll had made history [Germ. Maut])

Sozis ' 9 ' us (November 25th, 2016; allusion to Toys ' $و$ ' us; with a report on Socialdemocrats [= Sozis] who were making additional income through public marketing events)

The study of modified phraseological units provides insight into speakers' knowledge of these items. They function only if the original reference, i.e the phraseological basis, is known. In this context, the examples given above are revealing. They seem to indicate that the preferred items in the heute-show represent a specific type of phraseological Anglicisms, namely catchphrases, brand names and titles that have entered the German language together with the cultural product they designate, so-called cultural loans (Haspelmath, 2009, pp. 46-50). Indeed, 30 of the 50 units that this study is based on are:

- titles of films (which in Germany are often left in the original or are used together with the translated title: Verschollen - Cast away), e.g.:

A Nightmare on Wall Street (February 10th, 2017; cf. A Nighmare on Elm Street)

The Bodyguard (February 24th, 2017; showing Barack Obama and Angela Merkel)

White House Clown (November 11th, 2016; cf. Clownhouse)

- titles of pop songs or pop groups, e.g.:

We are the Bernd we are the Deutschland (January 27th, 2017; in reference to the AfD politician Björn Höcke - calling him 'Bernd' is a running joke in the program; cf. We are the world we are the people)

Cryan in the Rain (October 7th, 2016; in reference to John Cryan of Deutsche Bank AG; cf. Crying in the Rain)

Sisi Top (April 22nd, 2016; cf. ZZ Top), or 
- titles of TV programs or books:

Eurovision Hass Contest (January 27th, 2017; 'hate contest', in reference to a meeting of European right-wing politicians; cf. Eurovision Song Contest)

Fifty Shades of Orange (October 14th, 2016; in reference to the orange hue of Donald Trump's skin; cf. Fifty Shades of Grey)

Simplify your Türkei (November 18th, 2016; in reference to the Turkish President Erdoğan 'simplifying' or tidying up his country by abolishing several political parties; cf. Simplify your life)

The original names and slogans are established phrases that are perhaps not even perceived as foreign language items, so that their knowledge can be presupposed by the majority of viewers and not only by those who have a strong command of English. They are a result of the ubiquity of Anglo-American culture in German society. Franceschini (2009, p. 36) speaks of "unfocussed acquisition", i.e. "acquisition through exposure, without an explicitly chosen learning focus, a form of spontaneous acquisition through contact, incidental learning, learning en passant."

As the examples show, the words that are used to replace particular elements in the PUs are often phonetically similar to the original words, as (ein)mischen ['mI[n] and

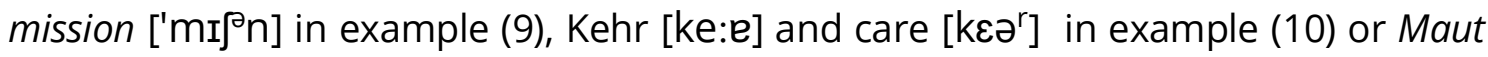
[maut] and mount [maunt] in example (12). Phonetic similarity (homophony or quasi-homophony) helps the viewer to recognize and understand the modifications.

As mentioned above, uses like these are not restricted to comedy shows. They abound in journalism and advertising. Little is known, however, of people's actual comprehension of those modifications of English phrases. The presence of a studio audience in a TV show can be helpful here. Viewer reactions, i.e. their spontaneous laughter and applause, allow us to see how successful a phraseologically based joke was. The following tables present excerpts from two programs of the heute-show illustrating the interplay between the anchor's monologue and captions on the screen, and also include viewer reactions.

\begin{tabular}{|l|l|l|l|}
\hline Time & Anchor's monologue & $\begin{array}{l}\text { Text in } \\
\text { the on- } \\
\text { screen } \\
\text { panel }\end{array}$ & $\begin{array}{l}\text { Audience's reac- } \\
\text { tion (@ symboli- } \\
\text { zes laughter) }\end{array}$ \\
\hline $26: 19$ & $\begin{array}{l}\text { Die Bundesregierung warnt diese } \\
\text { Woche vor einem neuen mächtigen }\end{array}$ & & \\
\hline
\end{tabular}




\begin{tabular}{|c|c|c|c|}
\hline & $\begin{array}{l}\text { Feind, vor so genannten Fake News } \\
\text { ['The Federal Government warns } \\
\text { about a new powerful enemy this } \\
\text { week, about so-called fake news'] }\end{array}$ & & \\
\hline \multirow[t]{2}{*}{$26: 26$} & Ja ['yes'] & $\begin{array}{l}\text { Fake dich } \\
\text { ins Knie } \\
\text { ['Fake } \\
\text { your own } \\
\text { knee'] } \\
\text { (see picture 2 }\end{array}$ & @@@@ (3 se-conds) \\
\hline & $\begin{array}{l}\text { Fake News, falsche Nachrichten } \\
\text { oder Hasskommentare (...) ['Fake } \\
\text { news, false news or hate } \\
\text { commentaries' ...] }\end{array}$ & & \\
\hline $27: 46$ & $\begin{array}{l}\text { (Topic: social bots) } \\
2017 \text { wird der erste Wahlkampf } \\
\text { sein, bei dem nicht nur Politiker } \\
\text { lügen, sondern auch Computer. } \\
\text { Ich sag nur USA. Donald Trump ist } \\
\text { nachweislich Präsident geworden } \\
\text { mit social bots und ['2017 will be } \\
\text { the first election campaign in which } \\
\text { not only politicians tell lies but also } \\
\text { computers. Donald Trump has } \\
\text { evidently become President by } \\
\text { means of social bots and'] }\end{array}$ & & \\
\hline \multirow[t]{2}{*}{$27: 56$} & Und ['and'] & $\begin{array}{l}\text { In Bot We } \\
\text { Trust (see } \\
\text { picture 3) }\end{array}$ & @ (1 second) \\
\hline & $\begin{array}{l}\text { Fake News und mit (...) ['Fake news } \\
\text { and with'] }\end{array}$ & & \\
\hline
\end{tabular}

Table 1. Excerpts of the heute-show aired on December 9th, 2016 


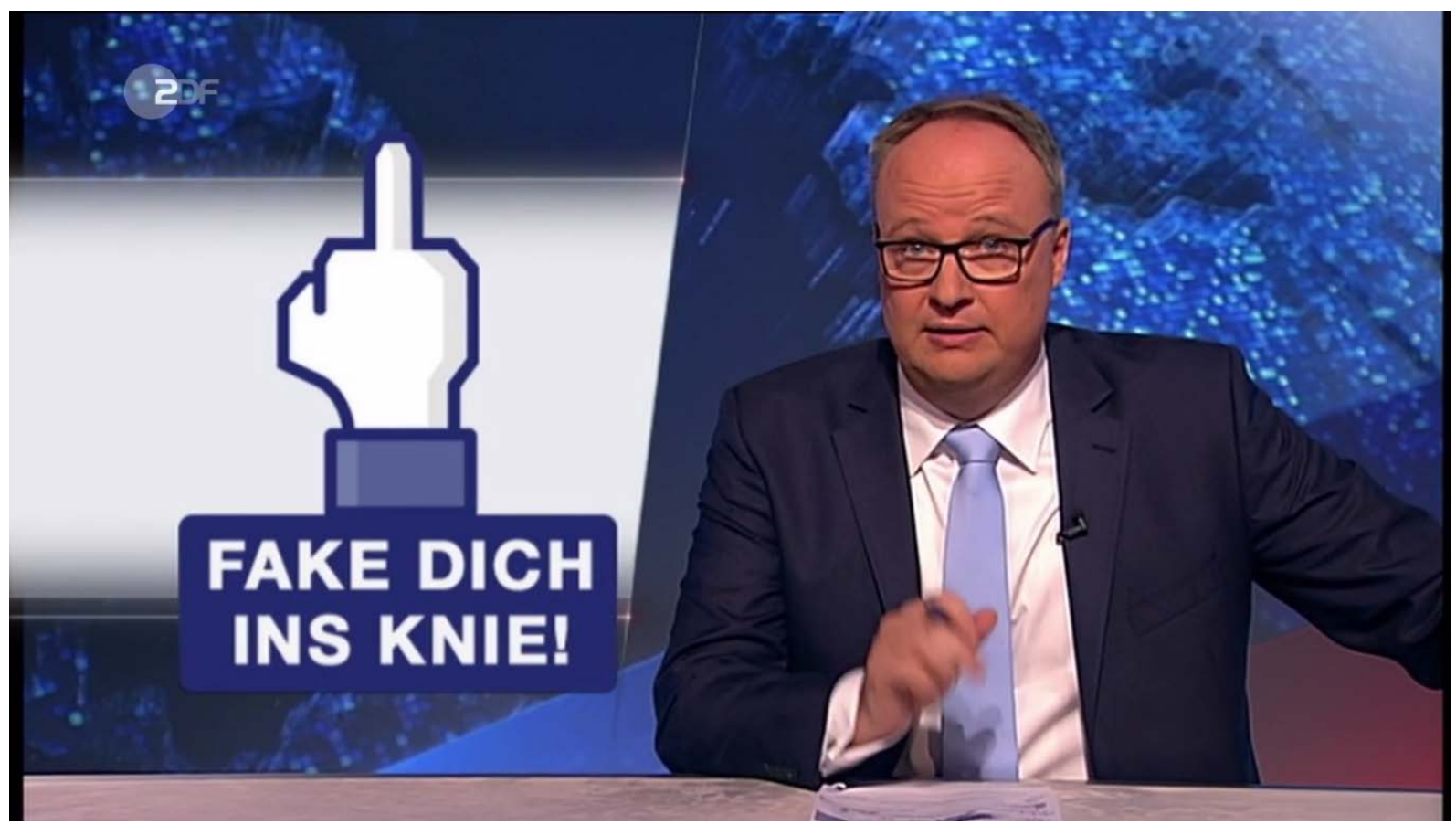

Picture 5. Screenshot from the 9th December program

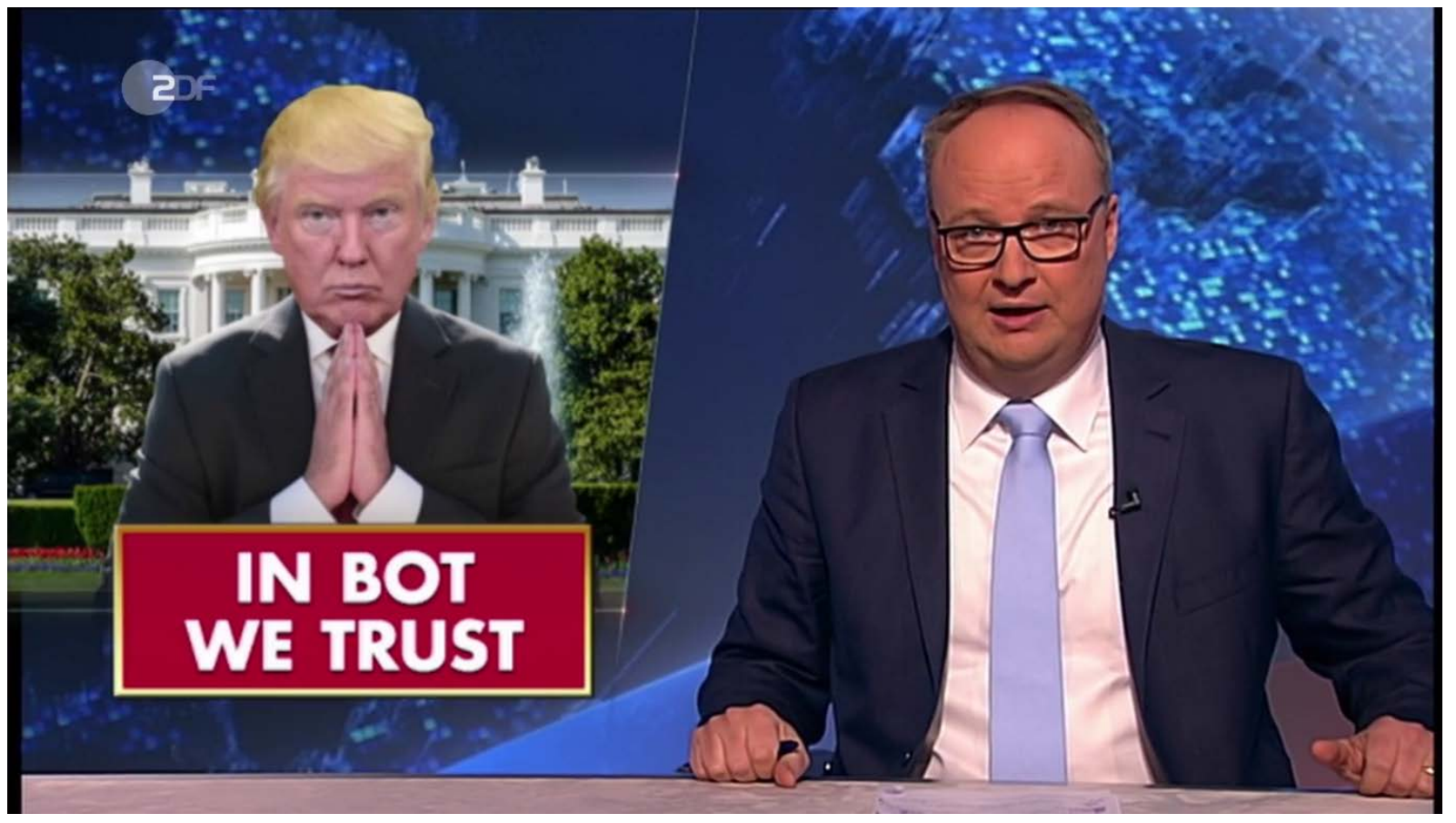

Picture 6. Screenshot from the December 9th episode

$\underline{\mathrm{C}}$ 


\begin{tabular}{|c|c|c|c|}
\hline Time & Anchor's monologue & $\begin{array}{l}\text { Text in the on-screen } \\
\text { panel }\end{array}$ & $\begin{array}{l}\text { Audience's } \\
\text { reaction (@ } \\
\text { symbolizes } \\
\text { laughter) } \\
\end{array}$ \\
\hline $13: 49$ & $\begin{array}{l}\text { So, liebe Zuschauer, Ihnen } \\
\text { muss ich das als politisch inte- } \\
\text { ressierte Menschen nicht sa- } \\
\text { gen. Am Sonntag ist es soweit } \\
\text { (...) der Ösi wählt schon wie- } \\
\text { der. Das Duell Van der Bellen } \\
\text { gegen Hofer. Schaffen es die } \\
\text { Österreicher endlich, einen } \\
\text { Bundespräsidenten zu wählen } \\
\text { ['Well, dear viewers, I don't } \\
\text { have to tell you as politically } \\
\text { interested people about it. } \\
\text { Sunday is the day ... when the } \\
\text { Oesi (=the Austrian citizen) } \\
\text { votes again. The duel between } \\
\text { Van der Bellen and Hofer. Will } \\
\text { the Austrians finally manage } \\
\text { to elect a head of state'] }\end{array}$ & & \\
\hline \multirow[t]{2}{*}{$14: 11$} & $\begin{array}{l}\text { Sie wissen das ist nicht so ihr } \\
\text { Ding, einmal hat man sich } \\
\text { wohl irgendwie verzählt, ne, } \\
\text { dann waren sie zu blöd, 'nen } \\
\text { Briefumschlag abzulecken (...) } \\
\text { ['you know, it's not their thing, } \\
\text { once they miscounted the } \\
\text { votes somehow, the second } \\
\text { time they were too stupid to } \\
\text { lick the envelopes ...'] }\end{array}$ & $\begin{array}{l}\text { It ain't over 'til it's } \\
\text { Hofer (see picture } \\
\text { 4) }\end{array}$ & (@) \\
\hline & $\begin{array}{l}\text { Video clip in which the politi- } \\
\text { cian Hofer's cat is the focus. It } \\
\text { is said that the cat shrinks } \\
\text { from meeting people it } \\
\text { doesn't know. }\end{array}$ & & @@@ \\
\hline $16: 46$ & $\begin{array}{l}\text { Der Kater von Hofer, der mag } \\
\text { keine Fremden, das ist ja ein }\end{array}$ & & @ \\
\hline
\end{tabular}




\begin{tabular}{|l|l|l|l|}
\hline & $\begin{array}{l}\text { Ding, du ['Hofer's cat doesn't } \\
\text { like foreigners'] }]^{13}\end{array}$ & \\
\hline $16: 51$ & & $\begin{array}{l}\text { Der spring- } \\
\text { ergestiefelte Kater } \\
\text { ['the cat in army } \\
\text { boots'/ 'Puss in } \\
\text { army boots'](see } \\
\text { picture 5) }\end{array}$ & $\begin{array}{l}\text { @@@@ seconds) } \\
\text { + applause }\end{array}$ \\
& & & \\
\hline $17: 06$ & Ein süßer Kater ['a sweet cat'] & & \\
\hline
\end{tabular}

Table 2. Excerpts from the heute-show aired on 2 December 2016

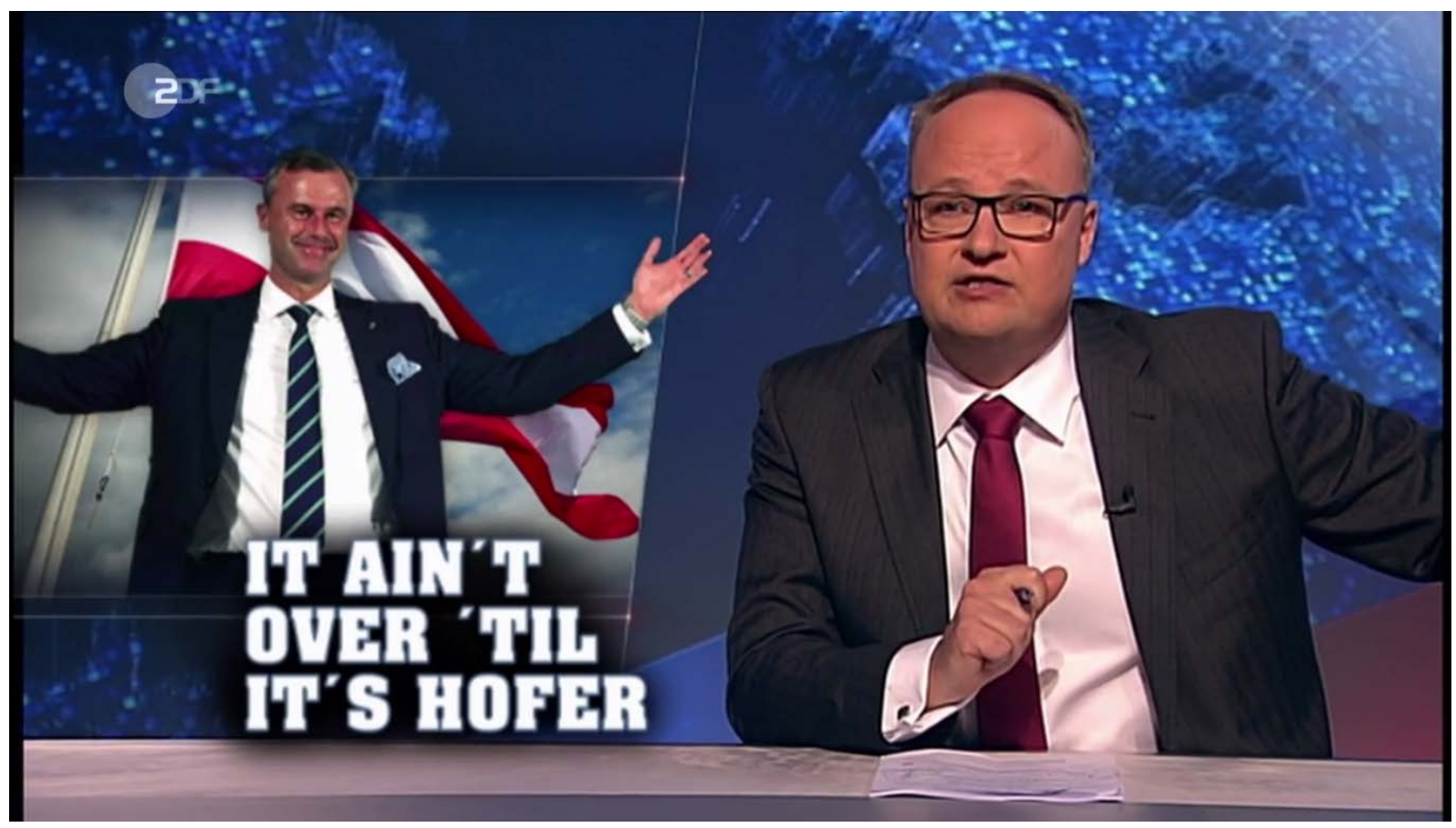

Picture 7. Screenshot from the December 2nd episode

13 The word Fremde can be understood in two ways here: (1) as people one is not familiar with (this is meant in the videoclip with reference to the cat) and (2) as 'foreigner', which is what the anchor is aiming at, in reference to the politician's xenophobic attitudes. 


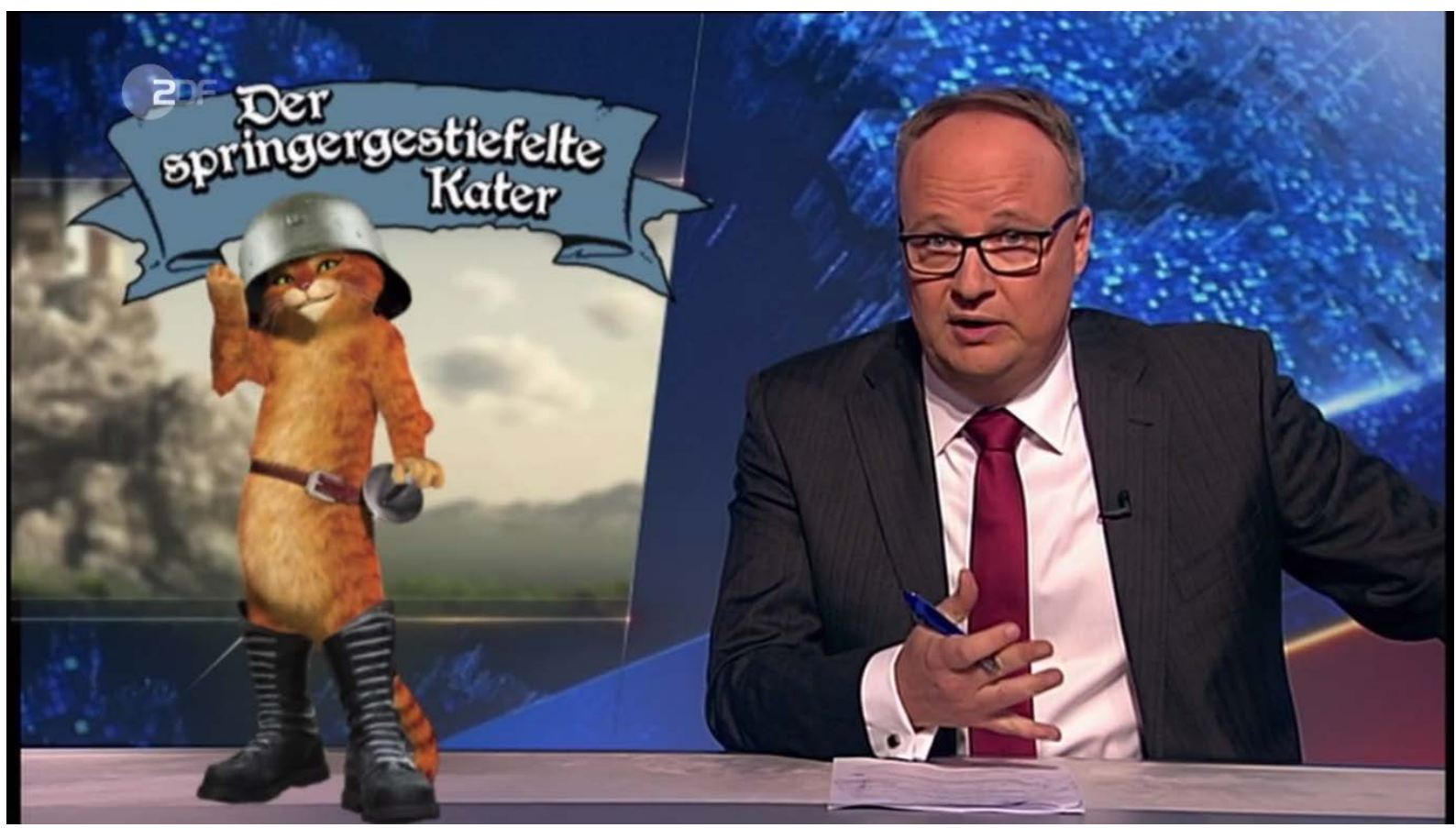

Picture 8. Screenshot from the December 2nd episode

The excerpts show that the audience receives the juxtaposed phraseological texts differently. The two German modified PUs (der springergestiefelte Kater and Fake dich ins Knie) are followed by significantly more laughter than the English expressions (In Bot We Trust and It ain't over 'til it's Hofer). An obvious reason for this is that the German items on which the humour is based (Fick dich ins Knie, lit. 'Fuck your own knee', cf. En. Go fuck yourself and der gestiefelte Kater - name of a fairy tale, cf. Puss in Boots) are immediately recognizable to the German-speaking audience (i.e., they can be immediately retrieved from their mental lexicon). This is different for phrases in a foreign language, here the modified motto of the USA, In God We Trust, and the catchphrase it ain't over 'til it's over. ${ }^{14}$ The latter item, which missed its mark with the audience, depended not only on the recognition of the phrase (e.g. due to the Lenny Kravitz song of the same name), but also on familiarity with the subject at hand. In order to understand the anchor's provocative message, its meaning 'Nothing is irreversible until the final act has played out' must be understood in the context of the Austrian election, which was rerun several times because of administrative irregularities. The less-than-enthusiastic reception of English PUs compared to that

14 A variant of the item, It ain't over 'til the fat lady sings, has entered the German language as a phraseological loan translation recently - Solange die dicke Frau noch singt, ist die Oper nicht zu Ende (Fiedler, 2014a, pp. 134-138). 
of the German ones supports Stefanowitsch's (2002, p. 76) assumption that evidence of a strong cultural influence, which is obvious in view of the large number of films and series of US origin shown by major TV networks, for example, is not to be equated with evidence for a linguistic influence. The result also reminds us of the studies by ENDMARK GmbH on the comprehension of English advertising slogans (e.g. Come in and find out; Driven by instinct; Good hair day, every day). Its representative surveys $(2003,2006,2009,2016)$ revealed that the contents of advertising claims were understood either not at all or not in the intended way by a majority of Germans. ${ }^{15}$ Our limited analysis is of course insufficient to generalize our finding to the use of phraseological Anglicisms in comedy programs broadly. Obviously, further studies are necessary, and these should also take into account the associated visual elements, like pictures (e.g. of the puss in boots cat), gestures (e.g. of giving the finger), and any video clips that precede the comments.

\section{Final remarks}

This study has shown that English has major impact on the German language. Influences can be observed at all levels of the linguistic system, including the phrasicon. Phraseological Anglicisms are frequently used in entertainment. The modification of phraseological units is a strategy that is often used in news satire such as the heute-show to serve both as entertainment and as political criticism. The deviation from a stable and expected structure produces comedic effects and the inclusion of lexical elements referring to topical political issues serves satirical purposes. Phraseological units borrowed from English (so-called phraseological Anglicisms) follow this strategy. In our pilot study of 20 episodes of the heute-show, they amount to about 30 per cent of the data set. The majority of phraseological Anglicisms are brand names, titles of films and songs, and political slogans. The preliminary analysis of their reception by the show's live audience suggests that they may be more difficult to understand than expected, despite the fact that the given items are supposed to be generally known to Germans due to their regular exposure to Anglo-American media. Further research in this field can help us to learn more about how well-established in German language and culture these items are and in general about the role that English loans play in German.

15 The 2016 survey showed that $64 \%$ of the participants did not understand the English claims they were asked about correctly. There were no significant differences dependent on participants' age (http://www.endmark.de/aktuelles/presse/claimstudie-2016/). 


\section{Article history}

Paper received: 6 March 2017

Paper received in revised form and accepted for publication: 5 May 2017

\section{About the Author}

Dr. Sabine Fiedler is Professor of English linguistics at the University of Leipzig, Germany. Her research interests include phraseology, text linguistics, translation and lingua franca communication. She has also studied pragmatics from a language-contact perspective, analysing English influence on other languages, especially German, in the field of phraseology. This research led to the publication of her 2014 book Gläserne Decke und Elefant im Raum - Phraseologische Anglizismen im Deutschen. Another publication is English Phraseology. A Coursebook (2007).

\section{Acknowledgements}

I would like to thank two anonymous reviewers for very helpful comments on an earlier draft of this article.

\section{References}

Barz, I. (2008). Englisches in der deutschen Wortbildung. In L.M. Eichinger, M. Meliss \& M. J. Dominguez Vasquez (Eds.), Wortbildung heute. Tendenzen und Kontraste in der deutschen Gegenwartssprache (pp. 39-60). Tübingen: Narr.

Bauer, L., Lieber, R. \& Plag, I. (2013). The Oxford Reference Guide to English Morphology. Oxford: Oxford University Press.

Baym, G. (2005). The Daily Show: Discursive integration and the reinvention of political journalism. Political Communication, 22(3), 259-276.

Braselmann, P. (2002). Globalisierung in Sprache und Kultur. Revue belge de philologie et d'histoire, 80 (3), 959-978.

Burger, H., Dobrovol'skij, D., Kühn, P. \& Norrick, N. R. (Eds.) (2007). Phraseologie. Phraseology. Ein internationales Handbuch zeitgenössischer Forschung. An International 
Handbook of Contemporary Research. Berlin \& New York: de Gruyter.

Burmasova, S. (2010). Empirische Untersuchung der Anglizismen im Deutschen. Bamberg: University of Bamberg Press.

Carstensen, B. (1965). Englische Einflüsse auf die deutsche Sprache nach 1945. Heidelberg: C. Winter.

Carstensen, B. \& Galinsky, H. (1963). Amerikanismen der deutschen Gegenwartssprache: Entlehnungsvorgänge und ihre stilistischen Aspekte. Heidelberg: Winter.

Emde, K. \& Scherer, H. (2016). Politische vs. persönliche Kritik: die Darstellung von Politikern in der Nachrichtensatire 'heute-show'. In P. Henn \& D. Frieß (Eds.), Politische Online-Kommunikation. Voraussetzungen und Folgen des strukturellen Wandels der politischen Kommunikation (pp. 119-139). Berlin (Digital Communication Research 3)

Fernando, C. (1996). Idioms and Idiomaticity. Oxford: Oxford University Press.

Fiedler, S. (2005). Phraseologismen in Comedy-Programmen: Die Harald-Schmidt-Show (2002-2003). In A. Heine, M. Hennig \& E. Tschirner, (Eds.), Deutsch als Fremdsprache. Konturen und Perspektiven eines Faches (pp. 181-198). München: IUDICIUM.

Fiedler, S. (2007). English Phraseology. A Coursebook. Tübingen: Narr.

Fiedler, S. (2014a). Gläserne Decke und Elefant im Raum. Phraseologische Anglizismen im Deutschen. Berlin: Logos Verlag.

Fiedler, S. (2014b). Scientific communication in a lingua franca. Język. Komunikacja.Informacja, 9, 48-57.

Fiedler, S. (2015). Phraseologie als Mittel der Satire: The Colbert Report 2012-2013. In C. Grandl, K. McKenna \& J. Kevin (Eds.), Dis dat, qui cito dat. Gegengabe in Paremiology, Folklore, Language, and Literature (pp. 531-539). Frankfurt/M.: Peter Lang.

Fink, H. (1970). Amerikanismen im Wortschatz der deutschen Tagespresse, dargestellt am Beispiel dreier überregionaler Zeitungen (Süddeutsche Zeitung, Frankfurter Allgemeine Zeitung, Die Welt). München: Hueber.

Franceschini, R. (2009). The genesis and development in reasearch of multilingualism: Perspectives for future research. In L. Aronin \& B. Hufeisen (Eds.), The Exploration of Multilingualism (pp. 27-62). Amsterdam: Benjamins.

Furiassi, C. (2010). False Anglicisms in Italian. Monza: Polimetrica.

Furiassi, C. \& Gottlieb, H. (2015). Pseudo-English. Studies on False Anglicisms in Europe. Berlin: De Gruyter Mouton.

Glahn, R. (2000). Der Einfluss des Englischen auf gesprochene deutsche Gegenwartssprache. Frankfurt/M.: Lang.

Gordon, M. D. (2015). Scientific Babel. The Language of Science from the Fall of Latin to the 
Rise of English. London: Profile Books.

Görlach, M. (2002). An Annotated Bibliography of European Anglicisms. Oxford: Oxford University Press.

Granger, S. (2009). Comment on: Learner Corpora: A Window onto the L2 Phrasicon. In A. Barfield \& H. Gyllstad (Eds.), Researching Collocations in Another Language. Multiple Interpretations (pp. 60-65). Houndmills: Palgrave Macmillan.

Haspelmath, M. (2009). Lexical borrowing: Concepts and issues. In M. Haspelmath \& U. Tadmor (Eds.), Loanwords in the World's Languages: A Comparative Handbook (pp. 3554), Berlin: de Gruyter.

Haugen, E. (1950). The Analysis of Linguistic Borrowing. Language, 26(2), 210-231.

Hüllen, W. (1992). Identifikationssprachen und Kommunikationssprachen. Über Probleme der Mehrsprachigkeit. Zeitschrift für germanistische Linguistik, 20(3), 298317.

Jones, J. P. (2010). Entertaining Politics: Satiric television and political engagement. Lanham, MD: Rowman \& Littlefield.

Kaplan, R. B. (1966). Cultural Thought Patterns in Inter-Cultural Education. Language Learning, 16, 1-20.

Kleinen-von Königslöw, K. \& Keel, G. (2013). Localizing The Daily Show: The heute-show in Germany. In G. Baym \& J. Jones (Eds.) New Parody and Political Satire Across the Globe (pp. 65-78). New York: Routledge.

Lawrenz, B. (2006). Zum Einfluss des Englischen auf die Morphologie der deutschen Sprache. Deutsch als Fremdsprache, 2, 98-102.

Lehnert, M. (1990). Anglo-Amerikanisches im Sprachgebrauch der DDR. Berlin: AkademieVerlag.

Lieber, R. (1992). Deconstructing Morphology: Word Formation in Syntactic Theory. Chicago: University of Chicago Press.

Norrick, N. R. (2007). Set phrases and humour. In H. Burger, D. Dobrovol'skij, P. Kühn \& N. R. Norrick (Eds.), Phraseologie. Phraseology. Ein internationales Handbuch zeitgenössischer Forschung. An International Handbook of Contemporary Research (pp.302-308). Berlin \& New York: de Gruyter.

Onysko, A. (2007). Anglicisms in German. Borrowing, Lexical Productivity, and Written Codeswitching. Berlin: de Gruyter.

Piller, I. (2001). Identity construction in multilingual advertising. Language in Society, 30, 153-186.

Crystal, D. (1998). Language Play. Harmondsworth: Penguin.

Postman, N. (1986). Amusing Ourselves to Death. Public Discourse in the Age of Show 
Business. Harmondsworth: Penguin.

Pulcini, V., Furiassi, C. \& Rodríguez González, F. (2012). The Lexical Influence of English on European Languages: From Words to Phraseology. In C. Furiassi, V. Pulcini \& F. Rodríguez González (Eds.), The Anglicization of European Lexis (pp. 1-24). Amsterdam \& Philadelphia: John Benjamins.

Quirk, R., Greenbaum, S., Leech, G. \& Svartvik, J. (1985). A Comprehensive Grammar of the English Language. London \& New York: Longman.

Schelper, D. (1995). Anglizismen in der Pressesprache der BRD, der DDR, Österreichs und der Schweiz: Eine vergleichende, typologische und chronologische Studie (Diss.). Universität Laval.

Schneider, K. P. (2015). Manufacturing Credibility: Academic Quoting Across Cultures. In J. Arendholz, W. Bublitz \& M. Kirner-Ludwig (Eds.), The Pragmatics of Quoting Now and Then (pp. 209-227). Berlin \& Boston: de Gruyter.

Stefanowitsch (2002). Nice to Miet You: Bilingual Puns and the Status of English in Germany. Intercultural Communication Studies, XI-4, 67-84.

Test, G.A. (1991). Satire, Art and Spirit. Florida: University Press.

Weinreich, U. (1953). Languages in Contact. Findings and Problems. New York: Weinreich.

Viereck, K. (1980). Englisches Wortgut: seine Häufigkeit und Integration in der österreichischen und bundesdeutschen Pressesprache. Frankfurt/M.: Lang.

Yang, W. (1990). Anglizismen im Deutschen. Tübingen: Niemeyer. 